Journal of Clinical Investigation

Vol. 43, No. 6,1964

\title{
The Influence of Hydrogen Ion Concentration and Hypoxia on the Pulmonary Circulation *
}

\author{
Yale Enson,† Carlo Giuntini, $\ddagger$ Milena L. Lewis, $\S$ Thomas Q. Morris, $\|$ \\ M. Irené Ferrer, and Réjane M. Harvey \\ (From the Department of Medicine, Columbia University, College of Physicians \& Surgeons, \\ and the Cardiopulmonary Laboratory of the First Medical Division and the \\ Chest Service, Columbia University Division, Bellevue Hospital, \\ New York, N. Y.)
}

Pulmonary hypertension has been found to be reversible in certain patients with cor pulmonale due to chronic bronchitis, bronchiolitis, and/or emphysema. In these individuals, as disturbances in gas exchange are corrected, pulmonary artery pressures fall (1). The high degree of correlation between the level of pulmonary artery pressures and the degree of hypoxemia $(2,3)$ as well as the pressor response to acutely induced hypoxia $(4,5)$ has implicated a reduced oxygen tension within the lungs as a major factor in the appearance of pulmonary hypertension (6). Since these patients almost invariably demonstrate hypercapnia, carbon dioxide tension has also been invoked as a cause of pulmonary hypertension (3). Anatomic reduction of the pulmonary vascular bed cannot be assigned a dominant role in the genesis of this hypertension because of its reversibility. Nonetheless, we may assume that the effects of reactivity of the vascular compartment to various stimuli will be more readily discernible in the presence of a restricted bed.

Liljestrand has recently come to the conclusion that an increased hydrogen ion concentration in the blood is the chemical stimulus for pulmonary

* Submitted for publication July 29, 1963; accepted February 6, 1964.

Supported by research grants HE-02001-08 and HE05,41 from the National Heart Institute, U. S. Public Health Service, and by a U. S. Public Health Service research career program award (5-K6-HE-16,603-02) from the National Heart Institute.

† Recipient of investigatorship of the Health Research Council of the City of New York under contract I-176.

$\ddagger$ Research fellow (HTS-5443) of the National Heart Institute.

§ Postdoctoral research fellow $(\mathrm{HF}-11,921-\mathrm{Cl})$ of the U. S. Public Health Service.

\| New York Heart Association research trainee, 19611962. vasoconstriction (7). He points out that hypoxia, by promoting release of lactic acid, and carbon dioxide retention will raise hydrogen ion concentration. He suggests that the blood hydrogen ion concentration which directly affects the pulmonary vasculature is dependent upon local hypoxia or hypercapnia; the reported variability in pressure response to acutely induced hypoxia or hypercapnia may therefore be due to local variations in ventilation and perfusion which these gases induce, as well as to their effect upon local hydrogen ion concentration.

In the light of Liljestrand's hypothesis the present study was undertaken to determine the effect of changing blood $\mathrm{pH}$ on the pulmonary artery pressures of patients with chronic pulmonary disease. Two groups of patients were studied: one received an infusion of sodium bicarbonate that caused a rise in blood $\mathrm{pH}$ and carbon dioxide tension but no change in arterial oxyhemoglobin saturation, and the other received an infusion of the organic buffer Tris, which resulted in an increase in blood $\mathrm{pH}$ and a fall in arterial oxyhemoglobin saturation.

As a consequence of the results obtained by raising blood $\mathrm{pH}$, we have also made a statistical analysis of the relationships among pulmonary artery mean pressure, arterial oxyhemoglobin saturation, and hydrogen ion concentration in a larger series of patients with chronic pulmonary disease taken from several sources.

\section{Methods}

Sixteen patients with chronic pulmonary disease were selected for this study. Thirteen had chronic bronchitis and emphysema : of these, eight had cor pulmonale ( $\mathrm{Pa}$ tients $1155,1247,1212,1352,1351,1298,1319$, and 1322), although none was considered to be in right heart fail- 
ure at the time of study. Two of the remaining patients had also recently recovered from right ventricular failure; in one (No. 1171) this resulted from multiple pulmonary thromboemboli and bronchiectasis with extensive fibrosis and in the other (No. 1184) from diffuse interstitial fibrosis secondary to tuberculosis. The remaining patient (No. 1232) had far-advanced pulmonary tuberculosis without cardiac involvement. There was no evidence of left ventricular enlargement or failure in any of the subjects. The details of their physical characteristics are given in Tables I and III.

Each patient was studied in the nonsedated, postabsorptive, basal state and was made familiar with the respiratory equipment the day before the test. Those

TABLE I

Effects of an infusion of sodium bicarbonate on blood flow and blood pressures in eight patients with chronic pulmonary disease

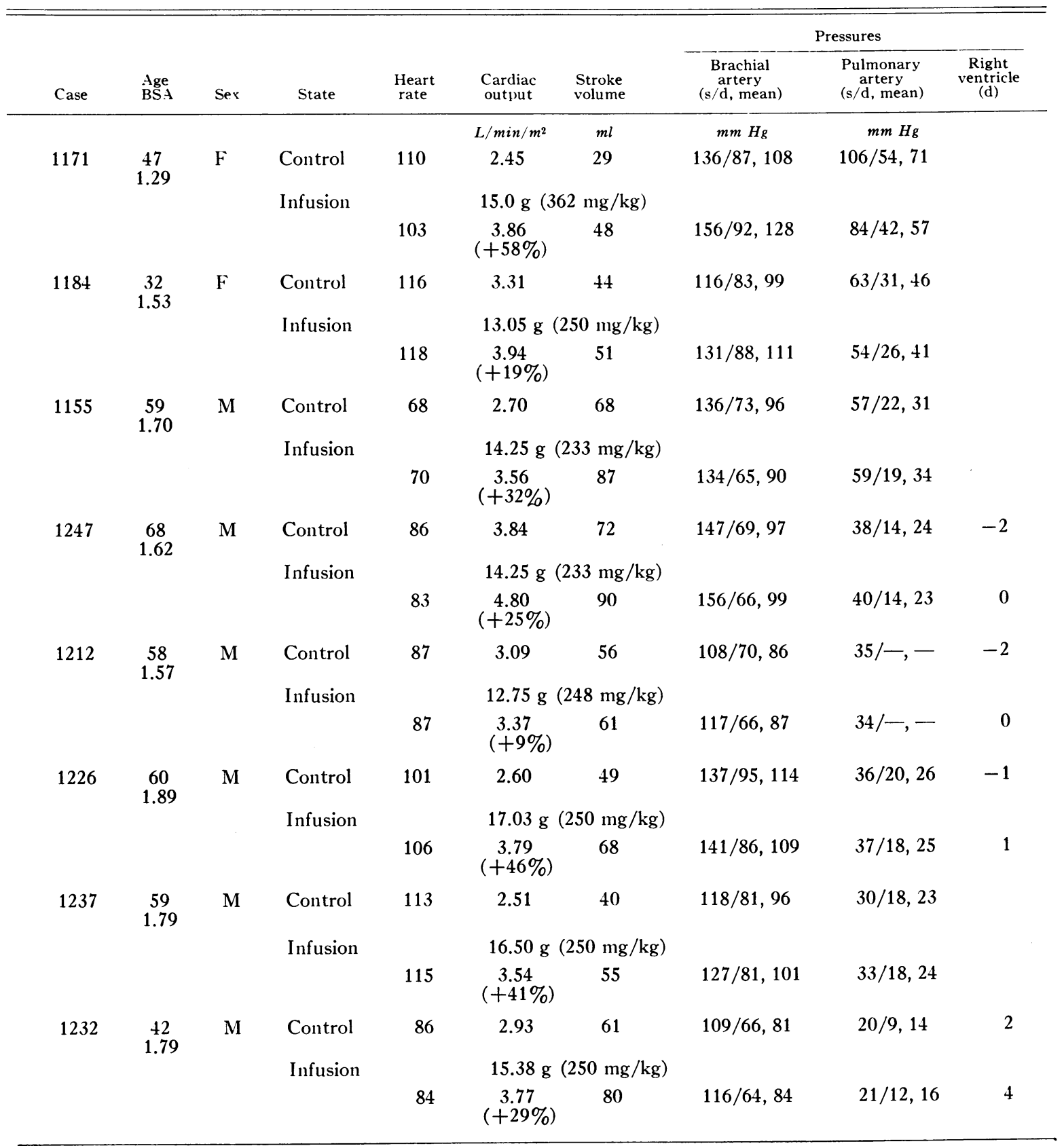


TABLE II

Effects of an infusion of sodium bicarbonate on ventilation, blood $p H$, and blood gases in eight patients with chronic pulmonary disease*

\begin{tabular}{|c|c|c|c|c|c|c|c|c|c|c|c|c|c|}
\hline Case & State & $\dot{\mathrm{V}} \mathrm{E}$ & $\mathrm{f}$ & $\dot{\mathrm{V}}_{2}$ & $\mathrm{Hgb}$. & $p \mathrm{Ha}$ & $\mathrm{CaO}_{2}$ & $\mathrm{Sa}_{2}$ & $\mathrm{PaCO}_{2}$ & $p H \overline{\mathbf{v}}$ & $\mathrm{C} \overline{\mathbf{v}}_{\mathrm{O}_{2}}$ & $\mathrm{~S} \overline{\mathrm{V}}_{\mathrm{O}_{2}}$ & $\mathrm{P} \overline{\mathrm{V}} \mathrm{CO}_{2}$ \\
\hline & & $L / m^{2}$ & $\begin{array}{l}\text { breaths/ } \\
\text { min }\end{array}$ & $\underset{m^{2}}{m l / \min }$ & $\underset{m l}{g / 100}$ & & $\underset{m l}{m l / 100}$ & $\%$ & $m m H g$ & & $\underset{m l}{m l / 100}$ & $\%$ & $m m H g$ \\
\hline \multirow[t]{2}{*}{1171} & Control & 4.84 & 24 & 120 & 12.2 & 7.31 & 11.7 & 70 & 54 & 7.29 & 6.8 & 40 & 60 \\
\hline & Infusion & 5.64 & 24 & 150 & 12.0 & 7.47 & 12.5 & 77 & 67 & 7.44 & 8.6 & 52 & 74 \\
\hline \multirow[t]{2}{*}{1184} & Control & 3.76 & 20 & 112 & 14.3 & 7.33 & 16.5 & 85 & 61 & 7.31 & 13.0 & 67 & 66 \\
\hline & Infusion & 3.63 & 20 & 114 & 13.5 & 7.48 & 15.4 & 84 & 65 & 7.46 & 12.5 & 68 & 67 \\
\hline \multirow[t]{2}{*}{1155} & Control & 6.21 & 30 & 138 & 15.2 & 7.41 & 18.0 & 87 & 48 & 7.38 & 12.9 & 62 & 56 \\
\hline & Infusion & 5.80 & 28 & 139 & 15.2 & 7.43 & 16.9 & 82 & 56 & 7.41 & 13.0 & 63 & 64 \\
\hline \multirow[t]{2}{*}{1247} & Control & 7.02 & 20 & 192 & 14.6 & 7.43 & 18.1 & 92 & 38 & 7.41 & 13.1 & 66 & 42 \\
\hline & Infusion & 7.30 & 16 & 191 & 14.0 & 7.54 & 17.2 & 90 & 46 & 7.52 & 13.2 & 69 & 52 \\
\hline \multirow[t]{2}{*}{1212} & Control & 5.71 & 16 & 149 & 15.1 & 7.39 & 17.5 & 85 & 58 & 7.37 & 12.7 & 62 & 63 \\
\hline & Infusion & 5.29 & 20 & 138 & 14.6 & 7.47 & 16.6 & 84 & 66 & 7.45 & 12.5 & 63 & 70 \\
\hline \multirow[t]{2}{*}{1226} & Control & 4.48 & 16 & 148 & 14.3 & 7.46 & 17.2 & 89 & 44 & 7.45 & 11.5 & 59 & 48 \\
\hline & Infusion & 4.34 & 14 & 148 & 13.3 & 7.56 & 15.5 & 86 & 53 & 7.54 & 11.6 & 64 & 57 \\
\hline \multirow[t]{2}{*}{1237} & Control & 4.37 & 20 & 121 & 14.0 & 7.39 & 16.9 & 89 & 49 & 7.37 & 12.1 & 63 & 53 \\
\hline & Infusion & 4.47 & 16 & 127 & 13.3 & 7.50 & 16.2 & 90 & 60 & 7.48 & 12.6 & 70 & 61 \\
\hline \multirow[t]{2}{*}{1232} & Control & 4.38 & 16 & 120 & 7.4 & 7.45 & 9.4 & 93 & 32 & 7.43 & 5.3 & 51 & 34 \\
\hline & Infusion & 4.85 & 18 & 132 & 7.1 & 7.58 & 8.9 & 90 & 39 & 7.56 & 5.4 & 55 & 41 \\
\hline
\end{tabular}

* Abbreviations: $\dot{\mathrm{V}} \mathrm{E}=$ expired gas consumption $; \mathrm{f}=$ respiratory frequency $; \dot{\mathrm{V}}_{2}=$ oxygen consumption $; \mathrm{Hgb}$. $=$ hemoglobin $; \mathrm{pHa}=\mathrm{ar}-$ terial $\mathrm{pH} ; \mathrm{CaO}_{2}=$ arterial oxygen concentration; $\mathrm{SaO}_{2}=$ arterial oxygen saturation; $\mathrm{PaCO}_{2}=$ arterial carbon dioxide tension; pHv $=$ mixed venous $\mathrm{pH} ; \mathrm{C}_{\mathrm{V}_{2}}=$ mixed venous oxygen concentration $\cdot \mathrm{S}_{\mathrm{O}_{2}}=$ mixed venous oxygen saturation and $\mathrm{P} \overline{\mathrm{V}}_{\mathrm{CO}_{2}}=$ mixed venous carbon dioxide tension.

eight patients who received sodium bicarbonate had a single or double lumen catheter placed in the pulmonary artery, or the right ventricle, or both, for the measurement of blood pressures and blood flow. A second catheter was introduced into the right atrium for the infusion of sodium bicarbonate, since preliminary studies had shown that a peripheral venous injection of this hypertonic solution caused local pain. In the eight patients who were given Tris, one catheter was placed in the pulmonary artery, and a second catheter, which had a double lumen, was advanced into the right atrium until its tip lay adjacent to the tricuspid valve. The distal lumen was utilized to inject radioiodinated human serum albumin (RISA) and the proximal lumen for the infusion of Tris. An indwelling Cournand needle was placed in a brachial artery.

The experimental protocol comprised a control period of 11 to 19 minutes during which an infusion of isotonic saline was maintained, followed by a period of approximately the same length during which the alkalinizing agents were infused at a constant rate. During each period three measurements were obtained of pulmonary artery or right ventricular and brachial artery pressures, or all three, and of ventilation and of arterial blood gases. Whenever blood pressures were recorded, the patients were not connected to the spirometer and were free of mouthpiece and noseclip. Blood flow was measured towards the end of each period as were venous blood gases. Cardiac output was determined according to the Fick principle in those patients who received sodium bicarbonate. RISA radiocardiograms were obtained at the end of the control period and sequentially during the Tris infusion for the measurement of cardiac output (8) and pulmonary blood volume (9). For brevity, only representative values are given in Tables I to IV. Complete data in four patients are plotted in Figures 1 to 4 .

In three instances (Patients 1352, 1351, and 1319) the protocol was modified during the early infusion of Tris, so that pressures in the pulmonary artery could be measured virtually continuously from 30 seconds before the onset of drug administration until 90 seconds after administration had begun. During this interval, blood flow and pulmonary blood volume were also measured by radiocardiography.

Total blood volume was estimated during the control period in five of the patients who received Tris with a single injection of Evans blue dye (T-1824) according to the method of Noble and Gregersen (10). Changes in blood volume were assessed during the infusion of Tris by measuring the departure of dye concentration from the semilogarithmic concentration-time curve established during the control period and by repeated measurements of hematocrit. Dye concentrations were read in plasma in a Beckman model DU spectrophotometer.

Ventilation and respiratory frequency were recorded on a Tissot spirometer.

Blood samples were analyzed for oxygen content and capacity and carbon dioxide content by the method of Van Slyke and Neill. Hemoglobin was determined from the oxygen capacity. The carbon dioxide tension was calculated from the whole blood carbon dioxide content with the line charts of Van Slyke and Sendroy. The 
carbon dioxide tension during Tris infusion was also calculated from the equation

$\left[0.0301 \mathrm{PaCO}_{2}\right]\left[\operatorname{antilog}\left(p K_{\mathrm{Tr}_{\mathrm{ris}}}-p K_{\mathrm{H}_{2} \mathrm{CO}_{3}}\right)\right]$

$$
\times\left[\frac{(\text { Tris })}{\text { (Tris }^{+}}\right]+0.0301 \mathrm{Paco}_{2}=\left(\text { total } \mathrm{CO}_{2}\right) S,
$$

using the values of Jorgensen and Astrup (11) for the ratio (Tris) $/\left(\right.$ Tris) ${ }^{+}$at various $\mathrm{pH}$ values to assess the validity of the $\mathrm{PaCO}_{2}$ values derived in the usual fashion. The $\mathrm{pH}$ of arterial and mixed venous bloods was determined with a Cambridge constant temperature $\mathrm{pH}$ meter in a few early studies and in the remainder with an Astrup radiometer. Respiratory gas samples were analyzed in a Scholander microanalyzer.
Two additional patients with chronic bronchitis and emphysema, having clinical and physiologic disturbances comparable to the other patients included in this paper, were studied to determine whether intrapulmonary arteriovenous shunts developed during Tris infusion. Intravenous injections of a mixed bolus of Evans blue and krypton $^{85}$ were made during the control and infusion periods, and the appearance of shunt was assessed according to the technique of Fritts and associates (12).

Sodium bicarbonate was administered as a $7.5 \%$ solution $(0.9 \mathrm{M})$, whereas $\operatorname{Tris}^{1}$ was given in $15 \%$ solution

1 Supplied through the courtesy of the Sigma Chemical Co., St. Louis, Mo.

TABLE III

Effects of an infusion of Tris and blood flow, pulmonary blood volume, and blood pressures in eight patients with chronic pulmonary disease

\begin{tabular}{|c|c|c|c|c|c|c|c|c|c|c|c|}
\hline \multirow[b]{2}{*}{ Case } & \multirow[b]{2}{*}{$\begin{array}{c}\text { Age } \\
\text { BSA }\end{array}$} & \multirow[b]{2}{*}{ Sex } & \multirow[b]{2}{*}{ State } & \multirow[b]{2}{*}{$\begin{array}{l}\text { Heart } \\
\text { rate }\end{array}$} & \multirow[b]{2}{*}{$\begin{array}{l}\text { Cardiac } \\
\text { output }\end{array}$} & \multirow[b]{2}{*}{$\begin{array}{l}\text { Stroke } \\
\text { volume }\end{array}$} & \multirow[b]{2}{*}{ PBV* } & \multirow[b]{2}{*}{$\begin{array}{l}\text { PMMT† } \\
\text { (heart } \\
\text { cycles) }\end{array}$} & \multicolumn{3}{|c|}{ Pressures } \\
\hline & & & & & & & & & $\begin{array}{c}\text { Brachial } \\
\text { artery } \\
\text { (s/d, mean) }\end{array}$ & $\begin{array}{l}\text { Pulmonary } \\
\text { artery } \\
\text { (s/d, mean) }\end{array}$ & $\begin{array}{c}\text { Right } \\
\text { ventricle } \\
\text { (d) }\end{array}$ \\
\hline \multirow{4}{*}{1352} & & & & & $L / \min / m^{2}$ & $m l$. & $m l$. & & $m m \mathrm{Hg}$ & $m m \mathrm{Hg}$ & \\
\hline & $\begin{array}{c}42 \\
2.03\end{array}$ & $\mathbf{M}$ & Control & 63 & 4.27 & 138 & 807 & 5.9 & $132 / 75,98$ & $55 / 29,37$ & \\
\hline & & & Infusion & & \multicolumn{2}{|c|}{$17.9 \mathrm{~g}(200 \mathrm{mg} / \mathrm{kg})$} & & & & & \\
\hline & & & & 78 & $\begin{array}{c}6.00 \\
(+41 \%)\end{array}$ & 156 & $\begin{array}{c}905 \\
(+12 \%)\end{array}$ & 5.8 & $121 / 63,82$ & $45 / 28,35$ & \\
\hline \multirow[t]{3}{*}{1351} & 59 & $\mathbf{M}$ & Control & 83 & 3.02 & 63 & 554 & 8.8 & $130 / 83,112$ & $46 / 23,33$ & \\
\hline & 1.73 & & Infusion & & \multicolumn{2}{|c|}{$12.6 \mathrm{~g}(200 \mathrm{mg} / \mathrm{kg})$} & & & & & \\
\hline & & & & 95 & $\begin{array}{c}3.72 \\
(+23 \%)\end{array}$ & 68 & $\begin{array}{c}702 \\
(+29 \%)\end{array}$ & 10.3 & $104 / 67,81$ & $48 / 23,31$ & \\
\hline \multirow[t]{3}{*}{1298} & 53 & $\mathbf{M}$ & Control & 104 & 2.92 & 43 & 363 & 8.4 & $163 / 98,123$ & $36 / 19,26$ & \\
\hline & 1.54 & & Infusion & & \multicolumn{2}{|c|}{$9.45 \mathrm{~g}(200 \mathrm{mg} / \mathrm{kg})$} & & & & & \\
\hline & & & & 113 & $\begin{array}{c}3.32 \\
(+14 \%)\end{array}$ & 45 & $\begin{array}{c}381 \\
(+8 \%)\end{array}$ & 8.5 & $138 / 86,109$ & $39 / 22,30$ & \\
\hline \multirow[t]{3}{*}{1319} & 71 & $\mathbf{M}$ & Control & 59 & 2.80 & 90 & 617 & 6.9 & $140 / 70,103$ & $36 / 17,22$ & 2 \\
\hline & 1.88 & & Infusion & & \multicolumn{2}{|c|}{$12.60 \mathrm{~g}(161 \mathrm{mg} / \mathrm{kg})$} & & & & & \\
\hline & & & & 58 & $\begin{array}{c}3.16 \\
(+13 \%)\end{array}$ & 103 & $\begin{array}{c}796 \\
(+29 \%)\end{array}$ & 7.7 & $122 / 69,95$ & $30 / 14,20$ & 6 \\
\hline \multirow[t]{3}{*}{1322} & 59 & $\mathbf{M}$ & Control & 77 & 2.41 & 49 & 451 & 9.2 & $120 / 74,92$ & $30 /-,-$ & -2 \\
\hline & 1.57 & & Infusion & & \multicolumn{2}{|c|}{$10.5 \mathrm{~g}(206 \mathrm{mg} / \mathrm{kg})$} & & & & & \\
\hline & & & & 80 & $\begin{array}{c}3.08 \\
(+28 \%)\end{array}$ & 61 & $\begin{array}{c}542 \\
(+20 \%)\end{array}$ & 8.9 & $107 / 63,80$ & $30 /-,-$ & 0 \\
\hline \multirow[t]{3}{*}{1303} & 62 & $\mathbf{M}$ & Control & 77 & 2.23 & 49 & 423 & 8.6 & $165 / 84,120$ & $22 i^{\prime}-,-$ & -3 \\
\hline & 1.68 & & Infusion & & \multicolumn{2}{|c|}{$12.6 \mathrm{~g}(219 \mathrm{mg} / \mathrm{kg})$} & & & & & \\
\hline & & & & 85 & $\begin{array}{c}3.01 \\
(+35 \%)\end{array}$ & 60 & $\begin{array}{c}506 \\
(+20 \%)\end{array}$ & 8.5 & $92 / 51,70$ & $19 /-,-$ & -3 \\
\hline \multirow[t]{3}{*}{1291} & 57 & $\mathbf{M}$ & Control & 63 & 2.68 & 67 & 388 & 5.8 & $152 / 80,111$ & $22 /-,-$ & -1 \\
\hline & 1.59 & & Infusion & & \multicolumn{2}{|c|}{$10.76 \mathrm{~g}(199 \mathrm{mg} / \mathrm{kg})$} & & & & & \\
\hline & & & & 75 & $\begin{array}{c}4.09 \\
(+53 \%)\end{array}$ & 87 & $\begin{array}{c}474 \\
(+22 \%)\end{array}$ & 5.4 & $140 / 74,102$ & $25 /-,-$ & -3 \\
\hline \multirow[t]{3}{*}{1364} & 54 & $\mathbf{M}$ & Control & 62 & 3.94 & 109 & 723 & 6.6 & $136 / 77,102$ & $20 / 7,12$ & \\
\hline & 1.71 & & Infusion & & \multicolumn{2}{|c|}{$11.70 \mathrm{~g}(200 \mathrm{mg} / \mathrm{kg})$} & & & & & \\
\hline & & & & 72 & $\begin{array}{c}5.05 \\
(+28 \%)\end{array}$ & 120 & $\begin{array}{c}749 \\
(+4 \%)\end{array}$ & 6.2 & $122 / 71,82$ & $18 / 7,10$ & \\
\hline
\end{tabular}

* PBV = pulmonary blood volume.

† PMTT = pulmonary mean transit time. 


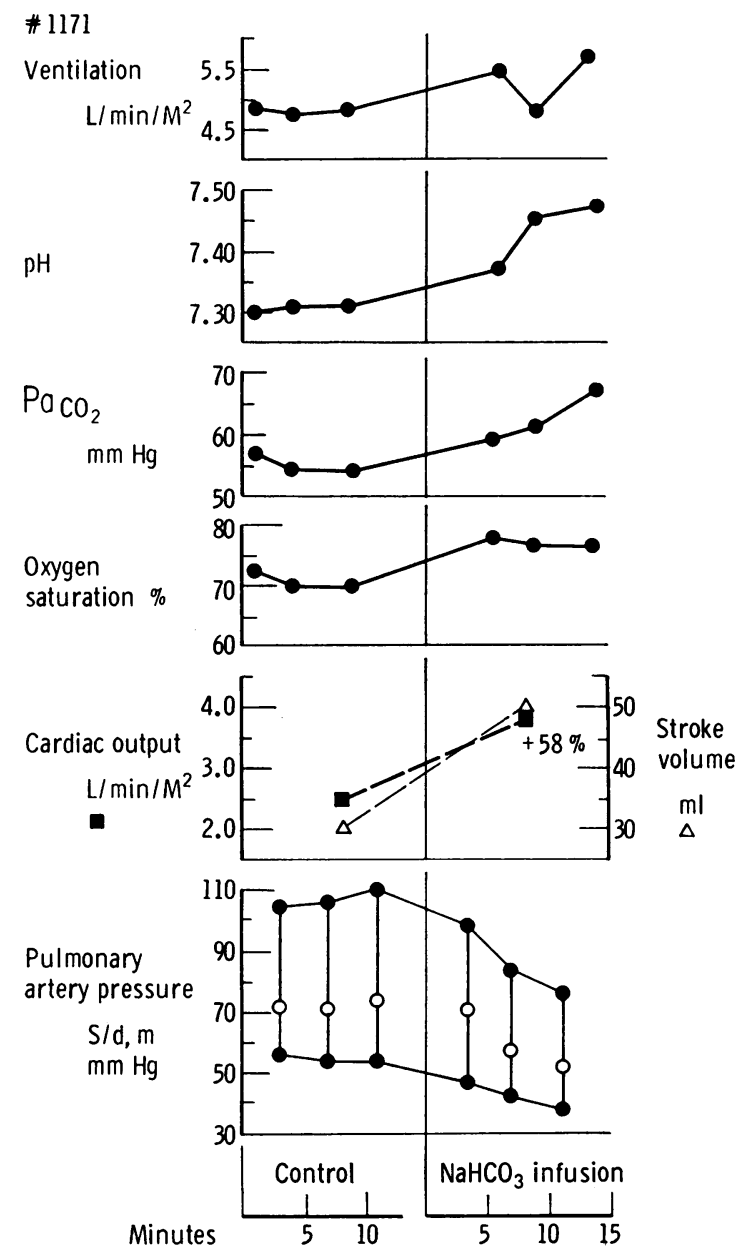

Fig. 1. Graphic RePresentation of the effects of sodium bicarbonate in Patient 1171.

(1.2 M). The total dose of drug given to each patient appears in Tables I and III.

\section{Results}

Sodium bicarbonate studies (Tables I and II, Figures 1 and 2). During the control period the average $\mathrm{pH}$ in the arterial and mixed venous bloods was 7.40 , with a range of 7.31 to 7.46 , and 7.38 , with a range of 7.29 to 7.45 , respectively. After drug administration the average rise in arterial and mixed venous $\mathrm{pH}$ was $0.11 \mathrm{U}$, with a range of 0.02 to $0.16 \mathrm{U}$.

The average change in ventilation was $+2 \%$, with a range of -7 to $+17 \%$.

All patients showed mild to severe hypoxemia before drug administration with one exception (No. 1232). The average change in arterial oxy- hemoglobin saturation was negligible; the range varied from +7 to $-5 \%$ saturation. There was an average rise in mixed venous oxyhemoglobin saturation of $4 \%$ (range, +1 to $+12 \%$ ).

All but two patients (No. 1247 and 1232) were hypercapneic during the control period, and arterial blood carbon dioxide tension increased in all patients with an average change of $9 \mathrm{~mm} \mathrm{Hg}$ (range, +4 to +13 ) during the infusion of bicarbonate. The mixed venous carbon dioxide tension showed a comparable rise.

During the infusion there was an average rise

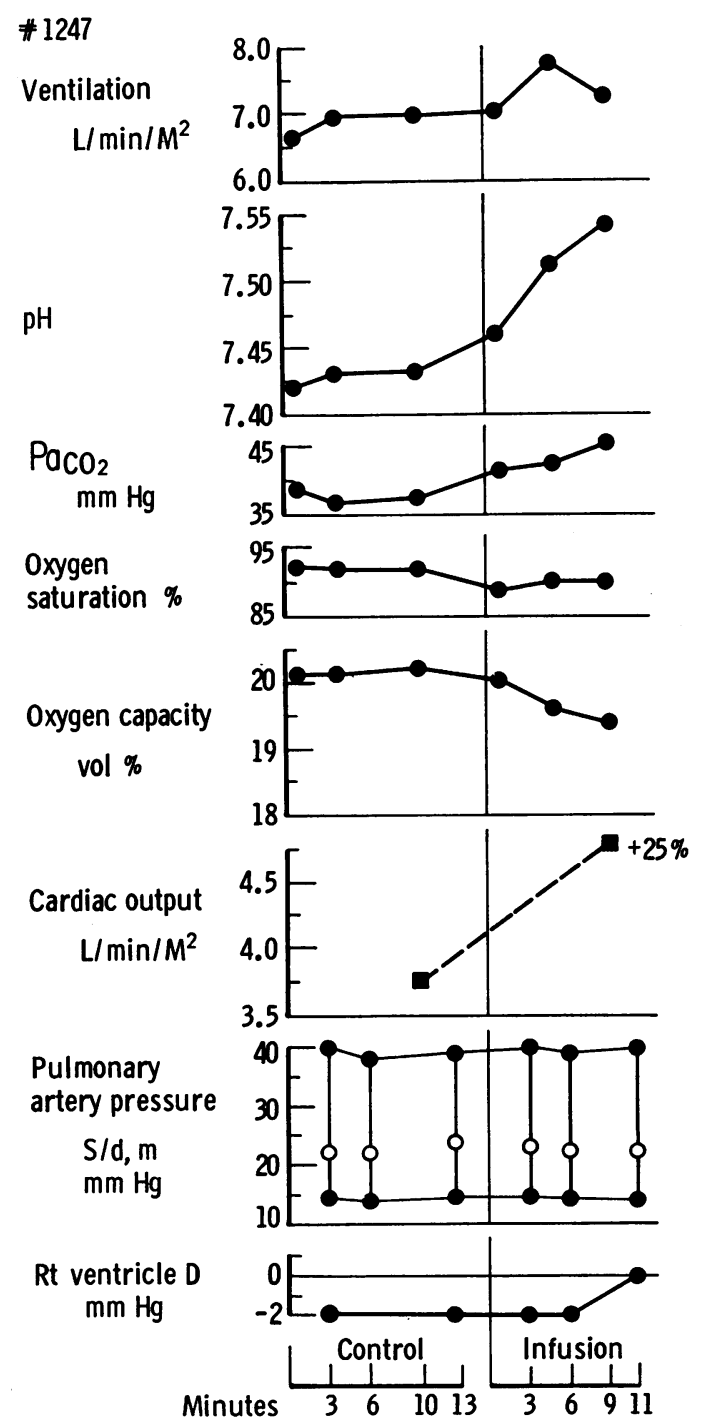

Fig. 2. Graphic Representation of the effects of SOdium BiCARbonate in Patient 1247. Rt ventricle D indicates right ventricular diastolic pressure. 


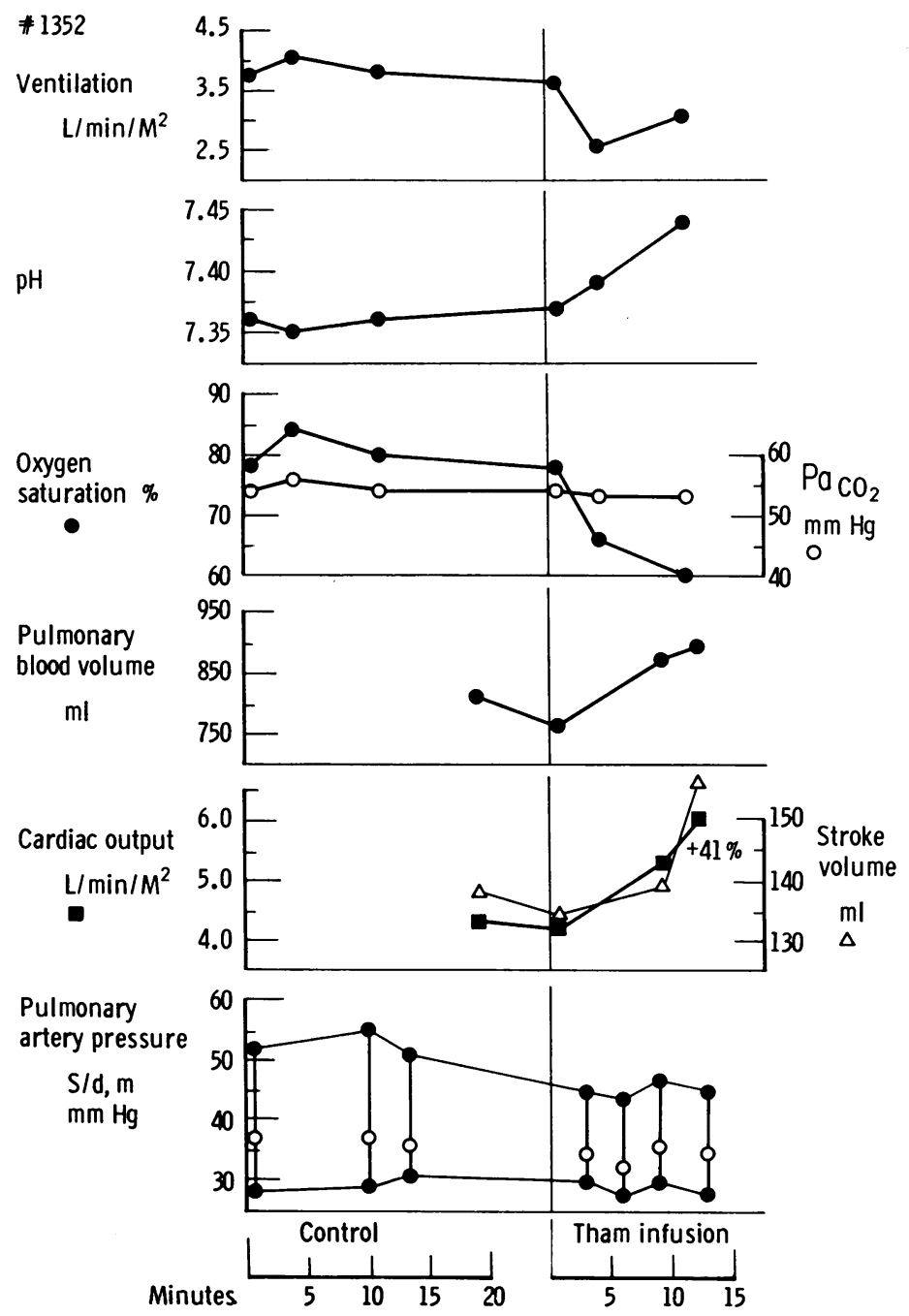

Fig. 3. Graphic Representation of the effects of Tris (Tham) in Patient 1352.

of $32 \%$ in cardiac output with a range of +9 to $+58 \%$. Stroke volume also rose an average of $30 \%$ with a range of +9 to $66 \%$.

In all but one patient (No. 1232), pulmonary hypertension existed, although it varied from mild to severe. In two patients (No. 1171 and 1184) the systolic, diastolic, and mean pressures fell during infusion of the alkali. In the remaining six, there was no significant change from preinfusion levels. There was little change in brachial artery pressures except in one patient (No. 1171), in whom these pressures rose.

During administration of sodium bicarbonate the heart rate did not vary by more than 7 beats per minute.
Tris studies (Tables III and IV, Figures 3 and 4). During the control period the average $\mathrm{pH}$ in the arterial and mixed venous bloods was 7.42 , with a range of 7.36 to 7.48 , and 7.40 , with a range of 7.34 to 7.46 , respectively. After Tris the average rise in arterial and mixed venous blood $\mathrm{pH}$ was $0.10 \mathrm{U}$ with a range of +0.06 to +0.14 units.

The ventilation fell markedly in seven of the eight patients during the infusion of Tris.

Six of the eight patients showed mild to moderate hypoxemia before the administration of Tris. During the infusion there was a fall in arterial oxyhemoglobin saturation in seven subjects, averaging $-16 \%$ saturation (range, -2 to $-20 \%$ ); 
the remaining patient (No. 1364) had an insignificant change. The oxyhemoglobin saturation of the mixed venous blood fell an average of $-13 \%$ saturation (range, -3 to $-18 \%$ ).

The level of carbon dioxide tension in the arterial blood during the control period was variable: low in one patient, elevated in three, and normal in the remaining four. When values for carbon dioxide tension were calculated with the line charts of Van Slyke and Sendroy, there was a slight fall in the average carbon dioxide tension during the infusion of Tris $(-3 \mathrm{~mm} \mathrm{Hg}$, range 0 to -8 ). If the considerations of Jorgensen and Astrup are included in the calculation of these values, there was a negligible change from control values. The mixed venous carbon dioxide tension fell in all but two cases (No. 1298 and 1291).

Mild to moderate pulmonary hypertension was present in four patients in the control period. During the infusion there was an early fall in sys-

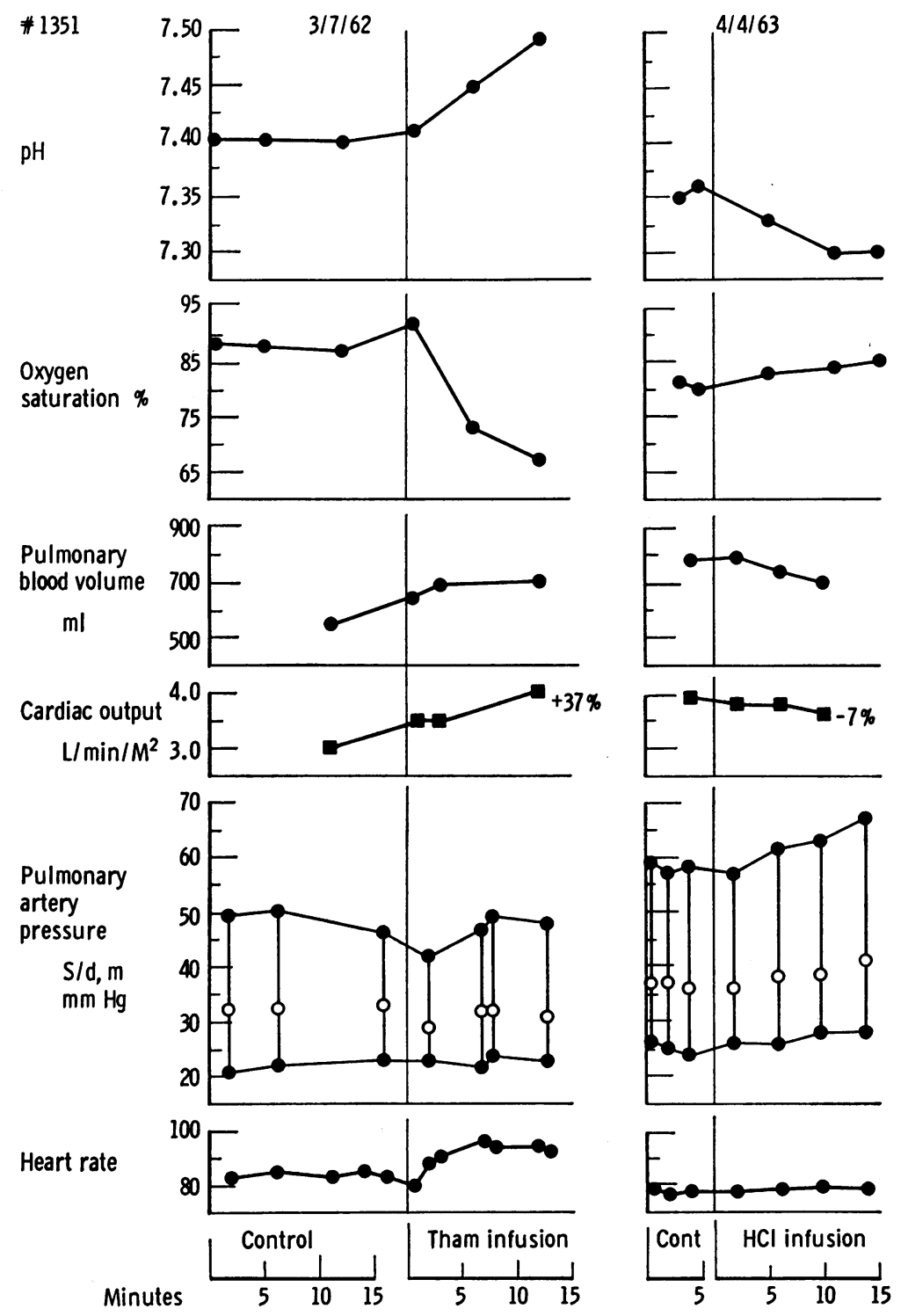

Fig. 4. Graphic representation of the effects of Tris (Tham) and OF HYDROCHLORIC ACID IN PATIENT 1351. The striking differences associated with the changes in $\mathrm{pH}$ are in oxygen saturation and in pulmonary blood volume, flow, and pressure. 
TABLE IV

Effects of an infusion of Tris on ventilation, $p H$, and blood gases in eight patients with chronic pulmonary disease

\begin{tabular}{|c|c|c|c|c|c|c|c|c|c|c|c|c|}
\hline Case & State & $\dot{\mathrm{V}} \mathrm{E}$ & f & $\mathrm{Hgb.}$ & $\mathrm{pHa}$ & $\mathrm{CaO}_{2}$ & $\mathrm{Sa}_{2}$ & $\mathrm{PaCO}_{2}$ & $\mathrm{pH} \overline{\mathbf{v}}$ & $\mathrm{C} \overline{\mathrm{v}}_{\mathrm{O}_{2}}$ & $\mathrm{SV}_{\mathrm{O}_{2}}$ & $\mathrm{P} \overline{\mathrm{V}}_{\mathrm{CO}_{2}}$ \\
\hline & & $L / \mathrm{min} / \mathrm{m}^{2}$ & $\begin{array}{l}\text { breaths/ } \\
\text { min }\end{array}$ & $\underset{\mathrm{gl}}{\mathrm{m} / 100}$ & & $\underset{m l}{m l / 100}$ & $\%$ & $m m H g$ & & $\underset{m l}{m l / 100}$ & $\%$ & $m m H g$ \\
\hline \multirow[t]{2}{*}{1352} & Control & 3.84 & 20 & 13.7 & 7.36 & 15.0 & 80 & 54 & 7.34 & 11.6 & 62 & 59 \\
\hline & Infusion & 3.09 & 17 & 13.4 & 7.44 & 11.1 & 60 & $50(53)^{*}$ & 7.43 & 8.3 & 45 & $50(52)$ \\
\hline \multirow[t]{2}{*}{1351} & Control & 5.63 & 29 & 16.9 & 7.40 & 19.7 & 87 & 43 & 7.38 & 15.5 & 68 & 49 \\
\hline & Infusion & 4.39 & 30 & 16.3 & 7.49 & 14.7 & 67 & $41(42)$ & 7.48 & 11.1 & 50 & $41(44)$ \\
\hline \multirow[t]{2}{*}{1298} & Control & 6.94 & 24 & 13.0 & 7.48 & 16.1 & 91 & 39 & 7.46 & 11.0 & 62 & 44 \\
\hline & Infusion & 5.68 & 32 & 12.4 & 7.55 & 12.8 & 76 & $40(41)$ & 7.52 & 8.3 & 49 & $43(45)$ \\
\hline \multirow[t]{2}{*}{1319} & Control & 4.44 & 22 & 17.3 & 7.37 & 19.8 & 85 & 52 & 7.35 & 15.2 & 65 & 56 \\
\hline & Infusion & 3.40 & 20 & 17.2 & 7.44 & 15.5 & 67 & $51(54)$ & 7.42 & 12.4 & 53 & $51(53)$ \\
\hline \multirow[t]{2}{*}{1322} & Control & 4.96 & 19 & 14.0 & 7.36 & 17.1 & 90 & 55 & 7.36 & 11.9 & 62 & 57 \\
\hline & Infusion & 3.13 & 16 & 14.3 & 7.50 & 13.5 & 70 & $47(49)$ & 7.49 & 9.5 & 48 & $48(49)$ \\
\hline \multirow[t]{2}{*}{1303} & Control & 5.48 & 20 & 13.3 & 7.48 & 16.4 & 91 & 40 & 7.46 & 11.1 & 61 & 43 \\
\hline & Infusion & 3.60 & 20 & 13.0 & 7.61 & 13.0 & 73 & $34(38)$ & 7.59 & 8.2 & 46 & $37(39)$ \\
\hline \multirow[t]{2}{*}{1291} & Control & 5.02 & 18 & 11.1 & 7.44 & 14.2 & 96 & 37 & 7.42 & 10.1 & 66 & 30 \\
\hline & Infusion & 3.82 & 20 & 11.0 & 7.51 & 12.0 & 80 & $37(40)$ & 7.49 & 8.6 & 57 & $39(42)$ \\
\hline \multirow[t]{2}{*}{1364} & Control & 6.02 & 18 & 12.2 & 7.46 & 15.7 & 95 & 33 & 7.43 & 11.3 & 68 & 36 \\
\hline & Infusion & 6.99 & 22 & 11.3 & 7.57 & 14.2 & 93 & $29(30)$ & 7.56 & 10.2 & 66 & $31(31)$ \\
\hline
\end{tabular}

* Number in parentheses indicates values for carbon dioxide tension calculated according to Jorgensen and Astrup.

tolic pressure in seven of the eight patients. In the two patients in whom this fall exceeded $5 \mathrm{~mm}$ $\mathrm{Hg}$ the cardiac output had not yet risen (Figure 5, No. 1352 and 1319). In the later minutes of the infusion period there was a negligible change in pressure in seven of the eight subjects at a time when all had experienced a rise in cardiac output, averaging $29 \%$. The heart rate rose in all patients, the average being 9 beats per minute. The pulmonary blood volume increased in all patients after the infusion of Tris; the average change was $91 \mathrm{ml}$ or $18 \%$. In the five patients in whom sequential measurements of both total blood and pulmonary blood volumes were obtained, the pulmonary blood volume averaged $10.2 \%$ of total blood volume before the infusion and rose to

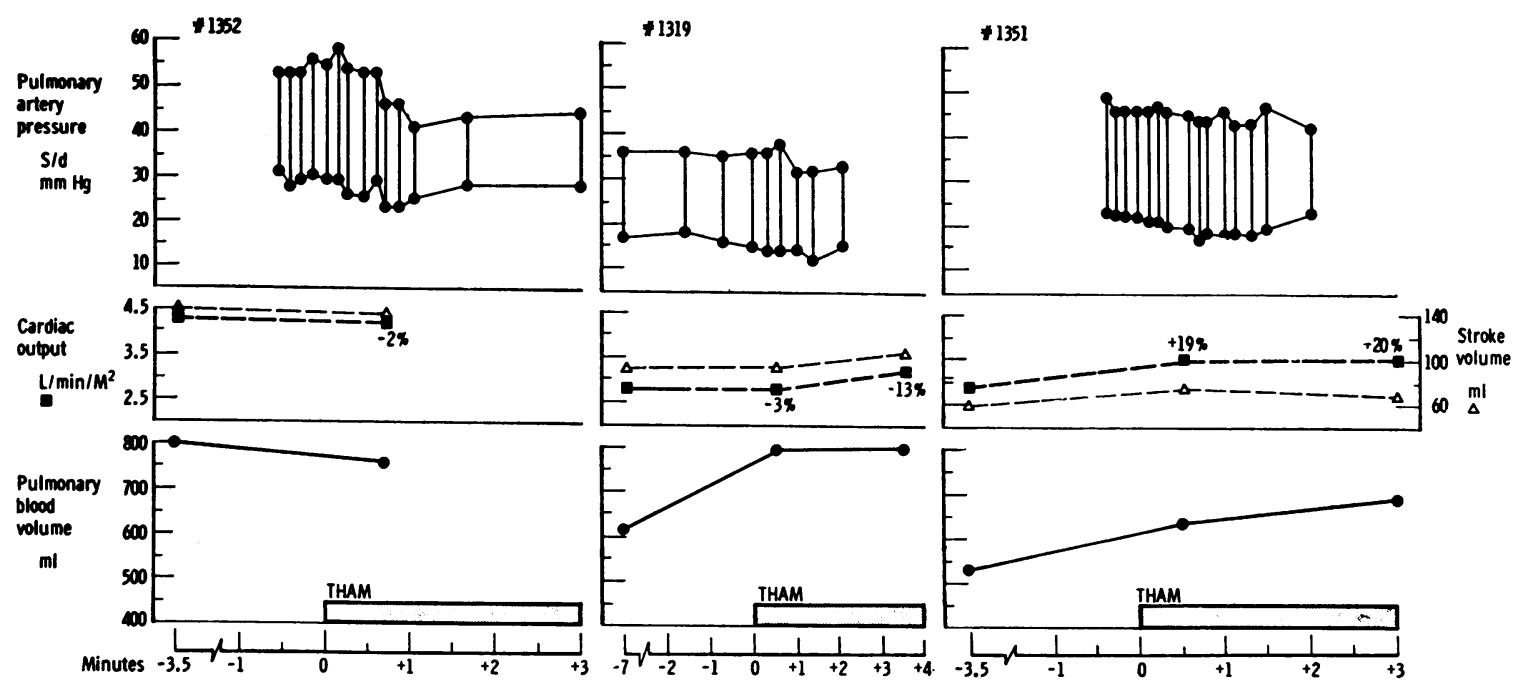

Fig. 5. Graphic representation of the effects of Tris (Tham) during the early minutes of adminisTRATION IN THREe DIFFERENT PATIENTS. Each systolic and diastolic point is the average value during one respiratory cycle. 
TABLE V

The effect of an infusion of Tris on pulmonary blood volume and on total blood volume*

\begin{tabular}{clcccr}
\hline Case & State & $\begin{array}{r}\mathrm{PBV} / \\
\mathrm{m}^{2}\end{array}$ & $\begin{array}{c}\mathrm{TBV} / \\
\mathrm{m}^{2}\end{array}$ & $\begin{array}{c}\mathrm{TBV} / \\
\mathrm{m}^{2}\end{array}$ & $\begin{array}{c}\mathrm{PBV} / \mathrm{TBV} \\
\times 100\end{array}$ \\
\hline \multirow{3}{*}{1352} & & $m l$ & $m l$ & $\Delta \%$ & \\
& Control & 398 & 3,891 & & 10.2 \\
& Infusion & 428 & 3,840 & -1.3 & 11.1 \\
1351 & Control & 320 & 3,357 & & 9.5 \\
& Infusion & 406 & 3,138 & -6.5 & 12.9 \\
1319 & Control & 328 & 3,697 & & 8.9 \\
& Infusion & 423 & 3,812 & +3.1 & 11.1 \\
1322 & Control & 287 & 3,005 & & 9.6 \\
& Infusion & 345 & 3,060 & +1.8 & 11.3 \\
& Control & 423 & 3,300 & & 12.8 \\
& Infusion & 438 & 3,332 & +1.0 & 13.2 \\
& Average before Tris infusion & & 10.2 \\
& Average during Tris infusion & -0.4 & 11.9 \\
\hline
\end{tabular}

$* \mathrm{PBV}=$ pulmonary blood volume $; \mathrm{TBV}=$ total blood volume

$11.9 \%$ during the infusion (Table V). The total blood volume itself did not change.

No intrapulmonary arteriovenous shunts were demonstrable during the control period in the two additional patients so studied (Table VI). Further, none could be identified during the infusion of Tris despite changes in arterial $\mathrm{pH}$ and oxyhemoglobin saturation of comparable magnitude to those encountered in the other eight patients who received Tris.

\section{Discussion}

This study demonstrates that a fall in blood hydrogen ion concentration causes pulmonary vasodilatation. This conclusion is based on a fall or no change in pulmonary artery pressure, despite changes in blood flow and blood gases usually productive of a rise in lesser circuit pressures in subjects with chronic obstructive disease of the lungs.

TABLE VI

The relationship of arterial oxyhemoglobin saturation and intrapulmonary arteriovenous shunts during Tris infusion*

\begin{tabular}{|c|c|c|c|c|c|}
\hline Case & State & $\dot{V} \mathrm{E}$ & $\mathrm{SaO}_{2}$ & $\mathrm{pHa}$ & $\dot{\mathrm{Q}}_{\mathrm{s}} / \dot{\mathrm{Q}}_{\mathrm{P}}$ \\
\hline & & $I . / m_{m^{2}} \min /$ & $\%$ & & $\%$ \\
\hline 1441 & $\begin{array}{l}\text { Control } \\
\text { Tris infusion }\end{array}$ & $\begin{array}{l}4.23 \\
4.18\end{array}$ & $\begin{array}{l}91 \\
78\end{array}$ & $\begin{array}{l}7.48 \\
7.56\end{array}$ & $\begin{array}{l}<1 \\
<1\end{array}$ \\
\hline 1443 & $\begin{array}{l}\text { Control } \\
\text { Tris infusion }\end{array}$ & $\begin{array}{l}5.79 \\
4.95\end{array}$ & $\begin{array}{l}89 \\
80\end{array}$ & $\begin{array}{l}7.39 \\
7.47\end{array}$ & $\begin{array}{l}<1 \\
<1\end{array}$ \\
\hline
\end{tabular}

* $\dot{\mathbf{Q}}_{\mathrm{s}}=$ shunt flow; $\dot{\mathrm{Q}}_{\mathrm{P}}=$ total pulmonary blood flow.
Previous investigations have established that the pulmonary vascular bed in this type of patient will respond to an acute increase in cardiac output by a rise in pressure $(1,13-18)$. The lack of pressure rise encountered in the present series and, indeed, the fall in pulmonary artery pressure obtained in the three patients (No. 1171, 1184, and 1352) who were acidotic before the infusion of the alkalinizing agents suggests that the decrease in blood hydrogen ion concentration had produced an increase in the capacity of the pulmonary vascular bed. This impression is strengthened by the observation that Tris-infusion was accompanied by an increase in pulmonary blood volume.

There have been numerous reports both in animals and in normal man that the inspiration of a gas mixture sufficiently low in oxygen to produce a reduction in arterial oxyhemoglobin saturation to the levels encountered in this series will be associated with an increase in cardiac output and pulmonary artery pressures. Fewer studies of the effect of inhalation of hypoxic mixtures in patients with chronic pulmonary disease have been published. Evidently, however, augmentation of pressures does occur, particularly if blood flow increases (19-21). A previous report from this laboratory on the effects of acute hypoxia on the circulation included five patients with pulmonary lesions similar to those in this series, who sustained a fall in arterial oxyhemoglobin saturation below $85 \%$ (20). In these subjects there was an average increase in pulmonary artery mean pressure of $8 \mathrm{~mm} \mathrm{Hg}$, associated with average increases in cardiac output of $16 \%$ and in arterial blood $\mathrm{pH}$ of only $0.03 \mathrm{U}(22)$. In all but one patient receiving Tris in the present report the oxygen saturation of the arterial blood fell a comparable degree and to similar levels, yet pulmonary artery pressures did not rise despite an average increase of $33 \%$ in blood flow ; however, the average rise in $\mathrm{pH}$ was $0.09 \mathrm{U}$. Apparently, a considerable fall in hydrogen ion concentration will prevent the pressor effect of hypoxia in this type of patient.

The mechanism of production of the observed fall in arterial oxygen saturation during Tris infusion deserves comment. Primary responsibility for this phenomenon resides in the diminished minute ventilation that occurred (23-26). Also, the rise in blood $\mathrm{pH}$ probably caused an increase in perfusion of the poorly ventilated portions 
of the lung, those hypoxic vascular segments most amenable to vasodilatation according to the hypothesis of Liljestrand (7), with consequent lowering of arterial oxygen tension. This possibility is bolstered by the fall in arterial oxyhemoglobin saturation which occurred during the infusion of Tris in Case 1441 (Table VI), since ventilation was virtually unchanged. The opening of anatomic pulmonary arteriovenous shunts has been excluded as playing a significant role in this process.

These observations on the effect of Tris in patients with pulmonary disease are at variance with those of Bergofsky, Lehr, and Fishman, who were unable to modify the pressor effect of hypoxia in normal man by the prior administration of Tris, although the fall in arterial oxyhemoglobin saturation and the actual levels of $\mathrm{pH}$ obtained were the same as were found in this study (27). The administration of Tris before the imposition of the hypoxic stimulus resulted in a smaller change in $\mathrm{pH}$ (average $+0.04 \mathrm{U}$ ) once hypoxia was induced than was encountered in the present series. There are insufficient data available to state whether a greater change in $\mathrm{pH}$ is needed to modify the effects of this stimulus in normal man, or whether such an effect can be demonstrated in the normal human pulmonary vascular system. Possibly, the response to an altered $\mathrm{pH}$ will only be detectable in the presence of chronic pulmonary disease.

Hypercapnia has been variably reported to cause either a rise in pulmonary artery pressures or no significant change in animals or in normal man. A slight rise in pulmonary artery pressures has been found in ten patients with pulmonary emphysema who sustained an average increase of $7 \mathrm{~mm} \mathrm{Hg}$ in $\mathrm{Pa}_{\mathrm{CO}_{2}}$ while breathing 3 or $5 \%$ carbon dioxide (28). This rise was ascribed to a concomitant rise in cardiac output that averaged $15 \%$. The patients in the present series who received sodium bicarbonate had an average rise in cardiac output of $32 \%$ and an average rise in $\mathrm{Pa}_{\mathrm{CO}_{2}}$ of $9 \mathrm{~mm} \mathrm{Hg}$, despite which pulmonary artery pressure either fell or remained unchanged. The differences between these two groups of patients were in the change in blood $\mathrm{pH}$ and in ventilation. In those who inspired high carbon dioxide mixtures there was an average fall of $0.06 \mathrm{pH} \mathrm{U}$ (29), whereas in those receiving sodium bicarbonate there was an average rise of $0.09 \mathrm{pH} \mathrm{U}$. The minute ventilation rose markedly in those breathing carbon dioxide and remained unchanged in those receiving bicarbonate. These data suggest that carbon dioxide per se is not responsible for changes in pulmonary artery pressure, but that the accompanying acidosis is. This concept is supported by the experiments of Bergofsky and associates, who showed in animals that acidosis produced by carbon dioxide inhalation in the absence of hyperventilation will produce a rise in pulmonary artery pressure (27).

Acidosis has been demonstrated to elicit a rise in pulmonary artery pressure during the infusion of acetic, hydrochloric, and lactic acids in animals $(27,30)$. As yet unpublished observations by the authors have shown that the infusion of $0.3 \mathrm{M}$ hydrochloric acid evokes a pressure rise in the pulmonary artery in man. Such a response is illustrated in Figure 4 in a patient who had previously experienced a fall in pressure during the infusion of Tris.

The influence of hypertonic solutions must also be considered in evaluating these pressure responses. A rise in pulmonary artery pressures has been produced in dogs by a variety of hypertonic solutions (31-37). Since Maxwell and associates also reported that hypertonic sodium bicarbonate produced a fall in pulmonary arterial resistance in association with a rise in arterial $\mathrm{pH}$ (38), it seems likely that failure of the pulmonary artery pressures to increase in the present study must be ascribed to the alkalizing effect of the solutions infused, rather than to their hypertonicity.

The demonstration that an acute change in hydrogen ion concentration could affect the pulmonary vasculature and modify the response to hypoxia in these patients prompted investigation of the sustained effects of these parameters in the control of pulmonary artery pressures in patients with similar types of chronic pulmonary diseases. Data which had been obtained in the steady state, at rest, and before any form of experimental manipulation were selected from 43 patients. Twelve of these subjects appear in the present paper; of the remaining 31 , each of whom had chronic bronchitis and emphysema, 13 are from the publication of Chidsey and associates (39), 7 from the work of Fishman, Fritts, and Cournand 


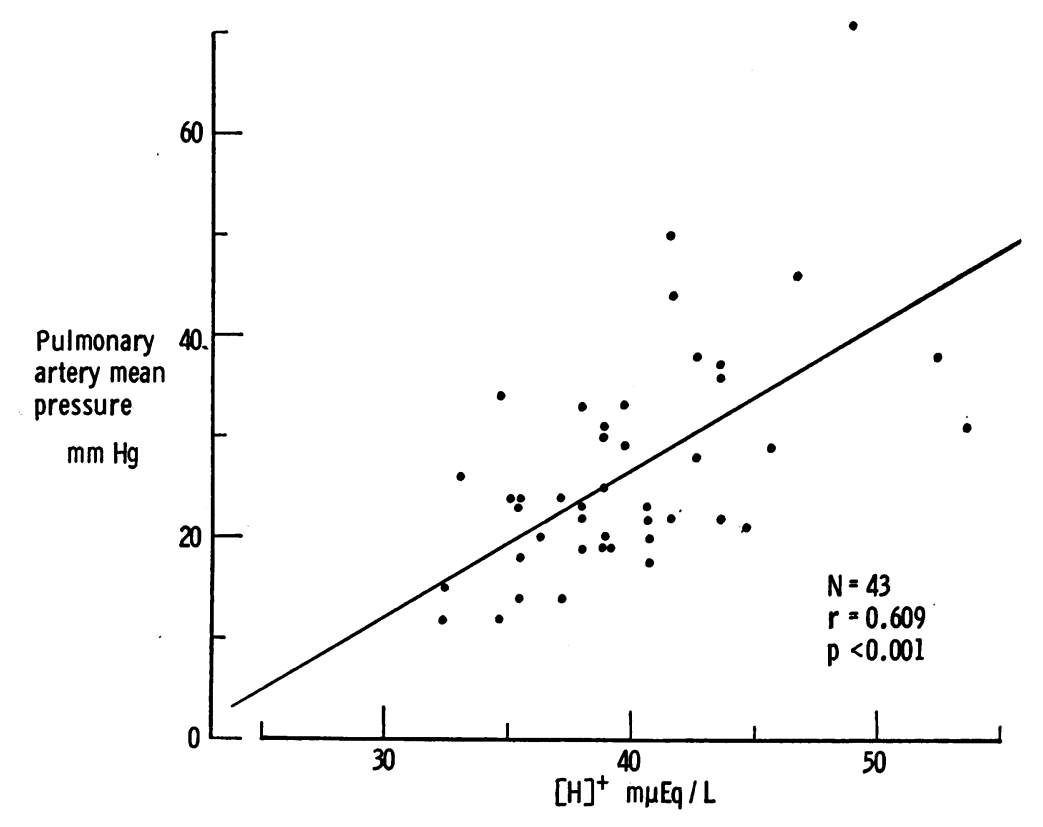

Fig. 6. GRAPHIC REPRESENTATION OF THE RELATIONSHIP BETWEEN HYDROGEN ION CONCENTRATION AND PULMONARY ARTERY MEAN PRESSURE IN 43 PATIENTS WITH CHRONIC PULMONARY DISEASE.

(28), and 11 represent previously unpublished studies of the present authors.

An analysis was made of the relationship between each of the following variables: hydrogen ion concentration, arterial oxyhemoglobin saturation, and pulmonary artery mean pressure.

A significant correlation was found between hydrogen ion concentration and pulmonary artery

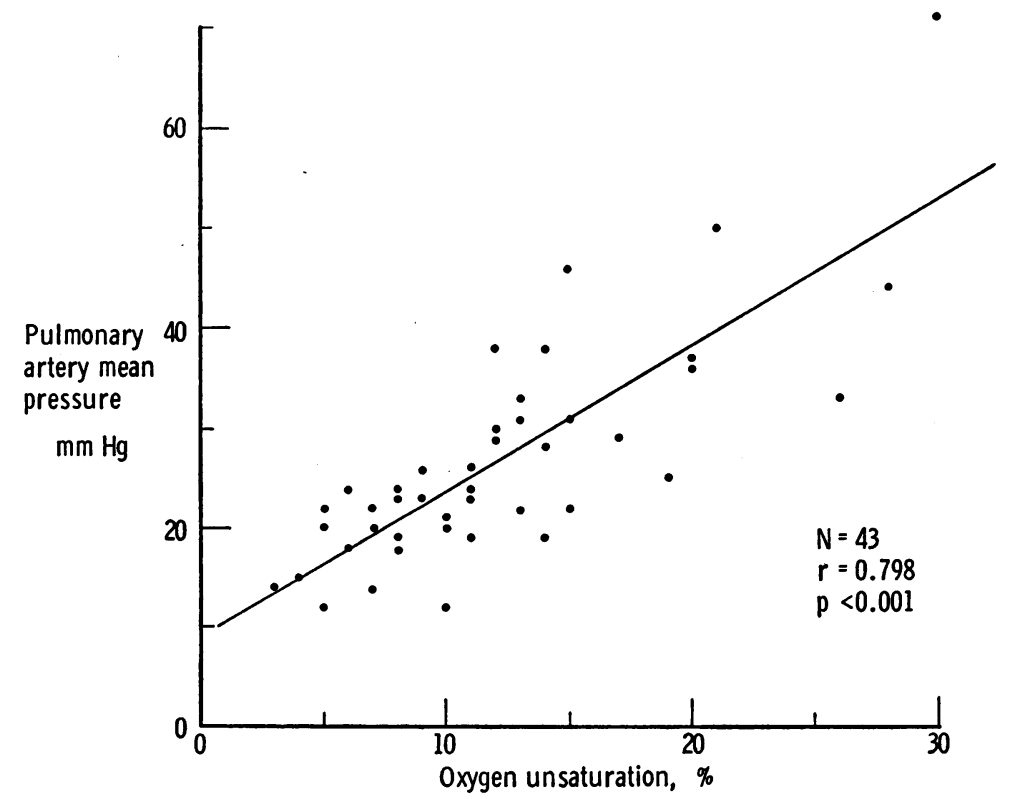

Fig. 7. Graphic RePRESENTAtion of the RELATIONSHiP BETWEen ARTERIAL BLOOD OXYHEMOGLOBIN UNSATURATION (100 MINUS THE SATURATION) AND PULMONARY ARTERY MEAN PRESSURE IN 43 PATIENTS WITH CHRONIC PULMONARY DISEASE. 
mean pressure as shown in Figure 6. A high degree of correlation was also found between arterial oxyhemoglobin saturation and pulmonary artery mean pressure, $r=0.798$. This relationship is shown in Figure 7, where unsaturation (100 minus saturation) rather than saturation of the arterial blood is plotted for convenience. There was also a significant correlation between oxyhemoglobin saturation and hydrogen ion concentration, $r=$ $0.521, \mathrm{p}<0.001$.

The coefficient of the multiple correlation between pulmonary artery mean pressure, hydrogen ion concentration, and arterial oxyhemoglobin unsaturation was found to be 0.830 , a value significantly different $(0.01<\mathrm{p}<0.05)$ from the coefficient of correlation between arterial oxyhemoglobin unsaturation and pulmonary artery mean pressure alone. Implicit in the derivation of this multiple correlation coefficient is that pulmonary artery mean pressure and oxyhemoglobin unsaturation of the arterial blood are related by a family of parallel isopleths of hydrogen ion concentration.

With these parallel isopleths we could not pre- dict pressure variations in a changing state of hypoxemia or of hydrogen ion concentration. This difficulty was overcome by assuming that the slope of the regression of pressure on one of the two independent variables changes at a constant rate with variations in the other. On this premise, Gomez has developed the following equation to express the relation among the three variables in a more complete manner:

$$
P=K+a H+b S+\omega H S,
$$

where $P=$ pulmonary artery mean pressure in $\mathrm{mm} \mathrm{Hg} ; K, a, b$, and $\omega$ are coefficients ; $S=$ arterial oxyhemoglobin unsaturation in percentage; and $H=$ hydrogen ion concentration in millimicroequivalents per liter. Equation 1 was multiplied successively by $H, S$, and $H S$, thus forming four simultaneous equations. Each equation was appropriately summated from the observed values for $P, H$, and $S$ of all 43 cases. This system of equations, containing the coefficients $K, a, b$, and $\omega$ as unknowns, was solved by the Gauss method of least mean squares. The values are as follows:

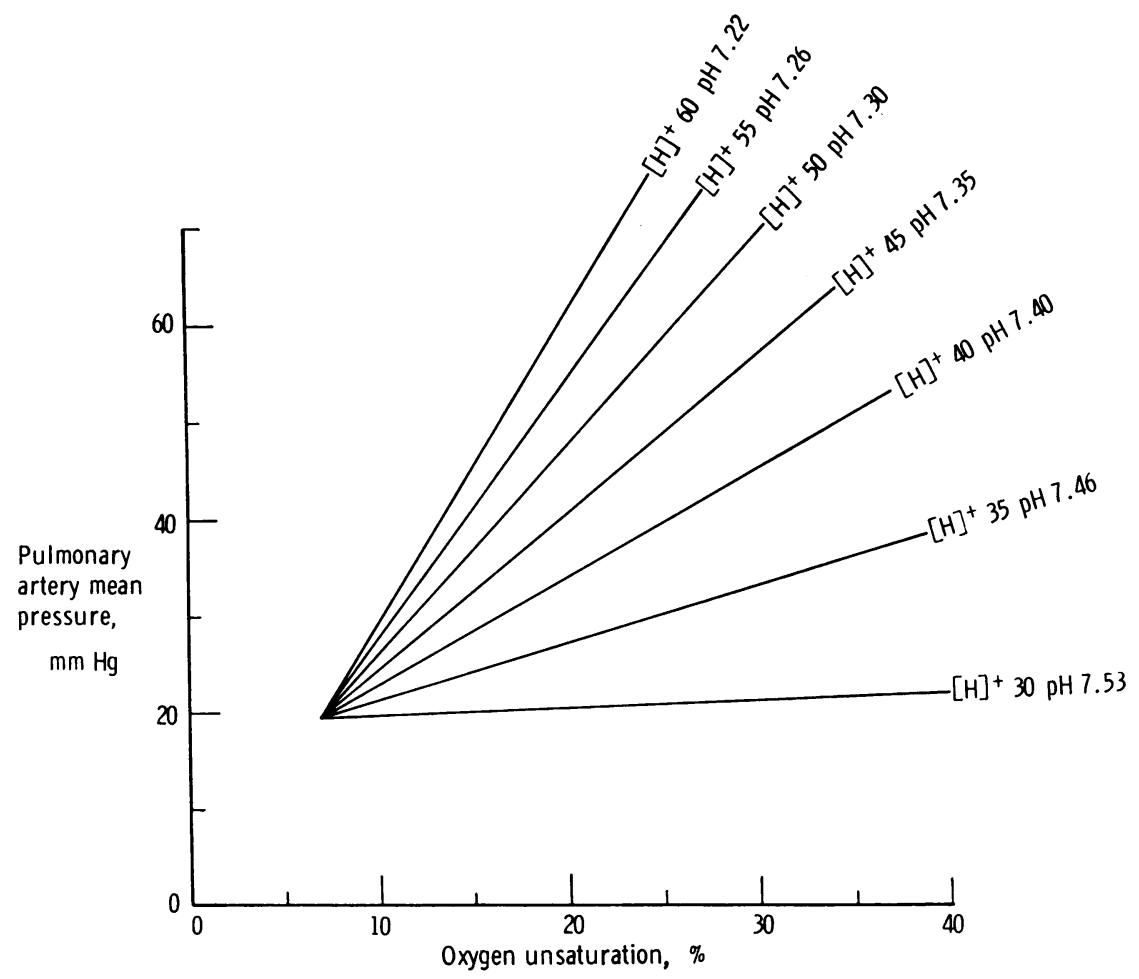

Fig. 8. GRaphic Representation of the relationship among pUlmonary aRTERY MEAN PRESSURE, ARTERIAL BLOOD OXYHEMOGLOBIN UNSATURATION, AND HYDROGEN iON CONCENTRATion as DERIVEd From EQuation 1. For discussion see text. 


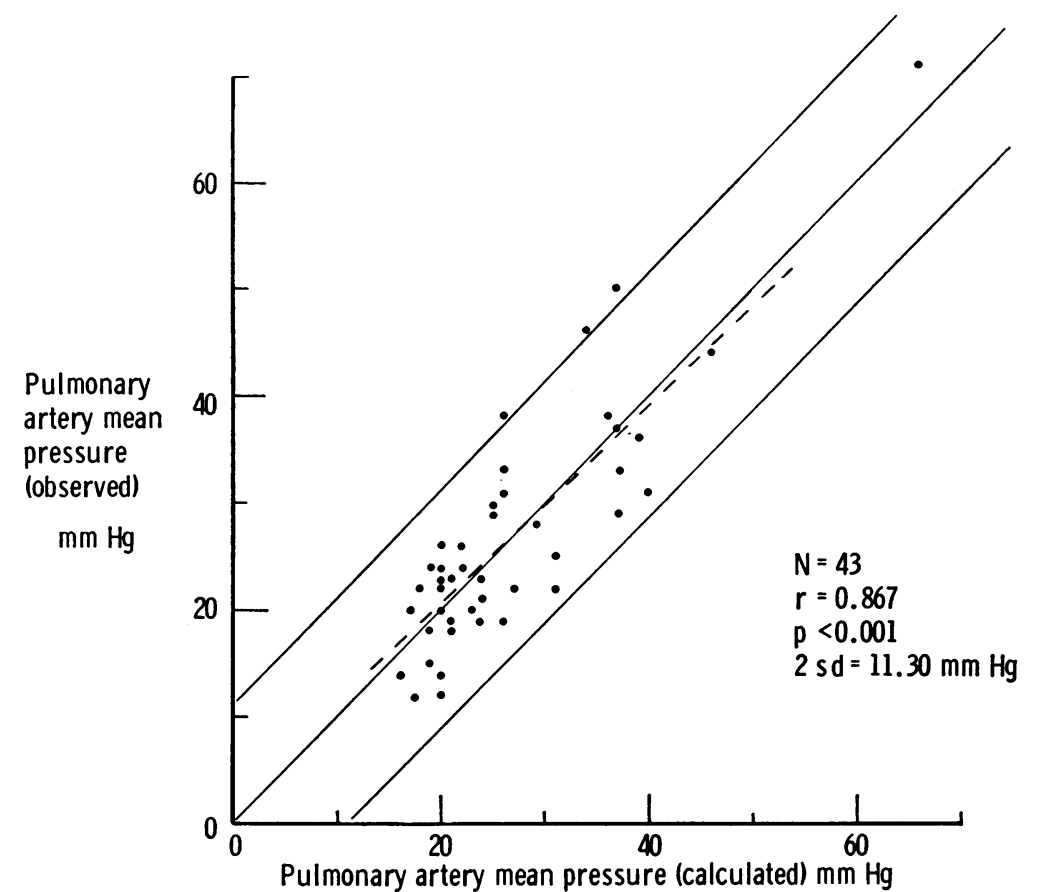

Fig. 9. Graphic Representation of the Relationship Between obSERVED PULMONARY ARTERY MEAN PRESSURE AND THAT CALCULATED FROM EQUation 1 in 43 patients with CHRONic pUlmonary disease. The regression and $95 \%$ confidence limits are included. The broken line indicates the regression obtained in 49 similar subjects with Equation 1. For discussion, see text.

$K=40.363, a=-0.713, b=-3.008$, and $\omega=$ 0.1028 . The relationship between $P$ and $H$ and $S$ is graphically illustrated in the family of curves derived from Equation 1 and shown in Figure 8. The pulmonary artery mean pressure at low concentrations of hydrogen ion is relatively insensitive to arterial oxygen unsaturation, whereas at high hydrogen ion concentrations the pressure is extremely sensitive to arterial oxygen unsaturation. As a corollary, at minor degrees of unsaturation pulmonary artery mean pressure is relatively insensitive to hydrogen ion concentration, whereas at high degrees of unsaturation it is extremely sensitive to hydrogen ion concentration.

Pulmonary artery mean pressure was calculated from Equation 1 for each of the 43 subjects from the hydrogen ion concentration and the arterial oxyhemoglobin unsaturation observed in each case and the four coefficients. The relationship between the calculated and observed pulmonary artery mean pressures is plotted in Figure 9. The correlation coefficient $(0.867, p<0.001)$ is significantly greater, $p<0.01$, than that of the simple multiple correlation.

To test the general applicability of this formulation, pulmonary artery mean pressure was calculated from the data of 49 similar patients whose values were not used in the original estimation of the coefficients of Equation 1. The regression observed on calculated pressure in these cases is also included in Figure 9. The standard deviation of the data about the regression is unchanged. The incorporation of these data in the determination of the coefficients would have had little effect on the value of the latter, and therefore a prediction of pressure based on Equation 1 may be made with the same degree of confidence as in the original population.

The changing state provides an additional test of the validity of this analysis if one can predict the magnitude and direction of a change in pulmonary artery pressure from the magnitude of change in both arterial oxyhemoglobin unsaturation and hydrogen ion concentration. The ob- 
served change in pulmonary artery mean pressure after the infusion of sodium bicarbonate or of Tris is plotted in Figure 10 against the change calculated for each patient by Equation 1. Also included are the data from the seven patients of Fishman and associates $(20,22)$, who inspired low oxygen mixtures. The latter were added to test the validity of this analysis in changing states associated with an increased pulmonary artery pressure. Except for one patient changes in pressure can be predicted reasonably accurately, although absolute levels of pressure in the changing state may not be so accurately gauged. Individual variations in structural and functional characteristics of the pulmonary vascular bed of the type of patient under consideration are probably responsible for the magnitude of standard deviation found in the calculation of pressure (Figure 9) as well as the lack of precision in predicting actual levels of pressure after a change in state.
Attempts to predict pulmonary artery mean pressure in normal subjects or in patients with pulmonary disease whose arterial oxyhemoglobin saturation lies above $93 \%$ have been unsuccessful; this may be due to the lesser reactivity of the pulmonary vascular bed in normal subjects or in patients without significant hypoxia.

This analysis indicates that, in the type of patient under consideration, pulmonary artery mean pressure is related to arterial oxyhemoglobin unsaturation, an index of pulmonary hypoxia, and blood hydrogen ion concentration in a more complex fashion than a merely additive one. One can speculate that hydrogen ion concentration and hypoxia are interacting stimuli, one either facilitating or inhibiting the effect of the other at the level of vascular smooth muscle. The concept of dual stimuli is consistent with the hypothesis of Liljestrand if both hypoxia and blood hydrogen ion concentration influence the

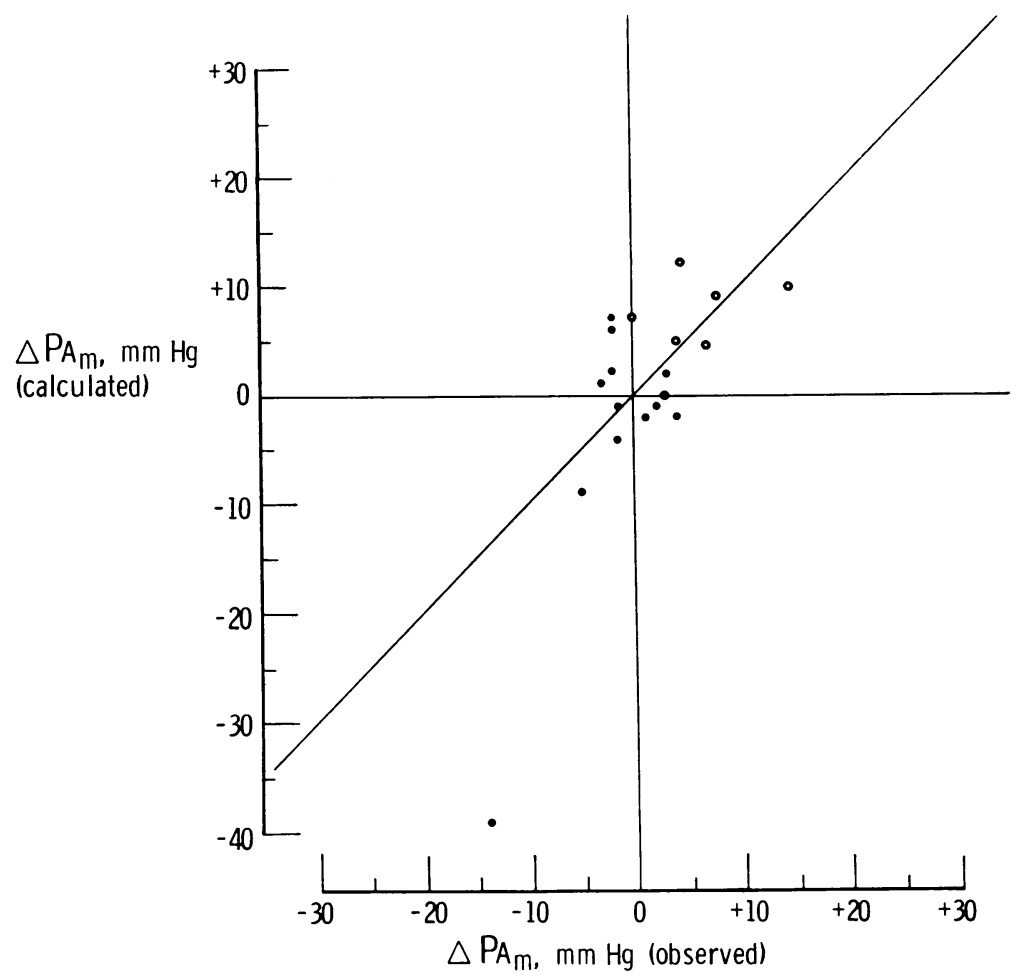

Fig. 10. Graphic representation of the relationship between obSERVED CHANGE IN PULMONARY ARTERY MEAN PRESSURE AFTER THE INFUSION OF TRIS OR OF BICARbonate (Closed Circles) aNd THAT CALCUlated FROM EQUATION 1. The open circles represent the relationship from data obtained in patients inspiring hypoxic mixtures. The line of $100 \%$ agreement is shown. 
production of intracellular lactic acid. The site of action remains unknown; it may be directly on the muscle cell or mediated by local receptors. Recent demonstrations that alveolar gas may diffuse through the walls of pulmonary precapillary vessels (40-42) emphasize the accessibility of these vessels to conditions in the surrounding pulmonary tissue. In patients where ventilation and perfusion are unevenly distributed, with consequent wide variations in the vascular environment, attention must henceforth be focused on the local blood and gas phases with which the vessel wall is in intimate contact in considering vasomotor reactivity.

\section{Summary}

The effects of alkalizing solutions on pulmonary hemodynamics were studied in 16 patients with chronic pulmonary disease.

In these patients the rise in blood $\mathrm{pH}$ was associated with a fall or with no change in pulmonary artery pressures despite increases in pulmonary blood flow and volume. Furthermore, in the presence of a rising blood $\mathrm{pH}$, severe hypoxia was not associated with a pressor response in the pulmonary artery. These observations suggest that a decrease in hydrogen ion concentration is associated with pulmonary vasodilatation.

The relationship among pulmonary artery mean pressure, arterial oxygen saturation, and hydrogen ion concentration was submitted to statistical analysis in 43 patients with chronic pulmonary disease.

Pulmonary artery mean pressure correlated with both oxygen saturation and hydrogen ion concentration to a significantly higher degree than with either of the two latter variables considered singly. $\Lambda t$ low concentrations of hydrogen ion (high $\mathrm{pH}$ ), pulmonary artery mean pressure is relatively insensitive to hypoxia as manifested by arterial oxygen saturation, whereas at high hydrogen ion concentrations (low $\mathrm{pH}$ ) pressure is extremely sensitive to hypoxia.

The mechanism whereby hydrogen ion concentration influences the pressor response to hypoxia is not clearly defined at present.

\section{Acknowledgments}

We thank Dr. Dickinson W. Richards for suggesting this study, Dr. André Cournand for his continuous help and advice, and Dr. Domingo Gomez for the mathematical formulation.

\section{Appendix}

\section{Derivation of Equation 1}

A. Analytic. Equation 1 was developed analytically for consideration of a system of one dependent and two independent variables.

or

$$
y=f(x, z)
$$

$$
P=f(H, S),
$$

where $P=$ pulmonary artery mean pressure, $H=$ hydrogen ion concentration, and $S=$ arterial oxyhemoglobin unsaturation.

It has been assumed that the second member of this equation is expansible in a power series so that

$$
P=K+a H+b S+c H^{2}+d S^{2}+\omega H S \ldots .
$$

Examination of the graphic relationship between the dependent and each of the independent variables considered singly (Figures 6 and 7), and between the independent variables revealed a linear relationship with a highly significant correlation in each case. For this reason it was considered justified, as a first approximation, to neglect all terms in the series expansion with exponents greater than one. Equation 1 results:

$$
P=K+a H+b S+\omega H S,
$$

which can also be written in the following two alternative forms :

and

$$
P=(K+a H)+(b+\omega H) S
$$

$$
P=(K+b S)+(a+\omega S) H .
$$

These equations map the relation of $P$ to $S$ or $P$ to $H$. In Equation d, $H$ is considered as a fixed parameter, and Figure 8 shows that the slope of the regression of $P$ on $S$ depends linearly on $H$. An analogous situation obtains when $S$ is the fixed parameter as in Equation e.

B. Statistical. The use of Equation 1 is also justified on statistical grounds for representing joint functional surfaces (43). The simplest expression of the relationship betwen a dependent and two independent variables is given by the multiple regression equation

$$
P=K+a H+b S \text {, }
$$

which implies a series of parallel isopleths of hydrogen ion concentration in the relation between pressure and saturation. This equation gives a representation of the relationship between $P, S$, and $H$ which is significantly better, $0.01<\mathrm{p}<0.05$, than that given by the simple linear regression between $P$ and $S$.

If it is assumed that $P$ varies linearly with $S$, and that the slope of the regression of $P$ on $S$ changes at a constant rate with changes in $H$, the joint functional relation is expressed by

$$
P=K+b S+\omega S H .
$$


If we expand the series further by assuming that $P$ varies linearly with both $S$ and $H$, and that the slope of the regression of $P$ on each independent factor changes at a constant rate with changes in the other independent variable, the relationship is described by

$$
P=K+a H+b S+\omega S H,
$$

which is the same as Equation $c$ of the analytic derivation. Both Equations $\mathrm{g}$ and $\mathrm{h}$ express the relationship between $P, S$, and $H$ in a significantly better manner, $\mathrm{p}<$ 0.01 , than Equation $f$. The indexes of correlation for Equations $\mathrm{g}$ and $\mathrm{h}$ are 0.860 and 0.867 , respectively, and their difference is sufficiently small to indicate that better regression surfaces capable of giving a further conspicuous reduction of the variance do not seem likely.

\section{References}

1. Ferrer, M. I., R. M. Harvey, R. T. Cathcart, C. A. Webster, D. W. Richards, Jr., and A. Cournand. Some effects of digoxin upon the heart and circulation in man. Digoxin in chronic cor pulmonale. Circulation 1950, 1, 161.

2. Borden, C. W., R. H. Wilson, R. V. Ebert, and H. S. Wells. Pulmonary hypertension in chronic pulmonary emphysema. Amer. J. Med. 1950, 8, 701.

3. Harvey, R. M., M. I. Ferrer, D. W. Richards, Jr., and $\mathrm{A}$. Cournand. Influence of chronic pulmonary disease on the heart and circulation. Amer. J. Med. 1951, 10, 719.

4. Euler, U. S. von, and G. Liljestrand. Observations on the pulmonary arterial blood pressure in the cat. Acta physiol. scand. 1946, 12, 301.

5. Motley, H. L., A. Cournand, L. Werko, A. Himmelstein, and D. Dresdale. The influence of short periods of induced acute anoxia upon pulmonary artery pressures in man. Amer. J. Physiol. 1947, $150,315$.

6. Rossier, P. H., and A. Bühlmann. Cor pulmonale et pathophysiologie alvéolaire. Cardiologia (Basel) 1954, 25, 132

7. Liljestrand, G. Chemical control of the distribution of the pulmonary blood flow. Acta physiol. scand. 1958, 44, 216.

8. Donato, L., D. F. Rochester, M. L. Lewis, J. Durand, J. O. Parker, and R. M. Harvey. Quantitative radiocardiography. II. Technic and analysis of curves. Circulation 1962, 26, 183.

9. Giuntini, C., M. L. Lewis, A. Sales Luis, and R. M. Harvey. A study of the pulmonary blood volume in man by quantitative radiocardiography. J. clin. Invest. 1963, 42, 1589.

10. Noble, R. P., and M. I. Gregersen. Blood volume in clinical shock. I. Mixing time and disappearance rate of T-1824 in normal subjects and in patients in shock; determinations of plasma volume in man from 10-minute sample. J. clin. Invest. 1946, 25, 158.

11. Jorgensen, K., and P. Astrup. The effect of 2-amino-2 hydroxymethyl-1, 3-propanediol on blood-buffering capacity. Ann. N. Y. Acad. Sci. 1961, 92 (2), 491.

12. Fritts, H. W., Jr., A. Hardewig, D. F. Rochester, J. Durand, and A. Cournand. Estimation of pulmonary arteriovenous shunt-flow using intravenous injections of $\mathrm{T}-1824$ dye and $\mathrm{Kr}^{85}$. J. clin. Invest. 1960, 39, 1841.

13. Ferrer, M. I., and R. M. Harvey. Decompensated pulmonary heart disease with a note on the effect of digitalis in Pulmonary Circulation, W. R. Adams and I. Veith, Eds. New York, Grune \& Stratton, 1958, p. 171.

14. Ozcan, R., N. Harmanci, N. Parla, and M. Bassipahi. Cedilanid in chronic cor pulmonale. Istanbul Contri. Clin. Sci. 1951, 1, 252.

15. Hickam, J. B., and W. H. Cargill. Effect of exercise on cardiac output and pulmonary arterial pressure in normal persons and in patients with cardiovascular disease and pulmonary emphysema. J. clin. Invest. 1948, 27, 10.

16. Riley, R. L., A. Himmelstein, H. L. Motley, H. M. Weiner, and A. Cournand. Studies of the pulmonary circulation at rest and during exercise in normal individuals and in patients with chronic pulmonary disease. Amer. J. Physiol. 1948, 152, 372.

17. Blount, S. G., Jr. Cardiac output in pulmonary emphysema in Pulmonary Circulation, W. R. Adams and I. Veith, Eds. New York, Grune \& Stratton, 1958, p. 160.

18. Fishman, A. P., H. W. Fritts, Jr., and A. Cournand. Effects of acute hypoxia and exercise on the pulmonary circulation. Circulation 1960, 22, 204.

19. Wescott, R. N., N. O. Fowler, R. C. Scott, V. D. Hauenstein, and J. McGuire. Anoxia and human pulmonary vascular resistance. $J$. clin. Invest. 1951, 30, 957.

20. Fishman, A. P., J. McClement, A. Himmelstein, and A. Cournand. Effects of acute anoxia on the circulation and respiration in patients with chronic pulmonary disease studied during the "steady state." J. clin. Invest. 1952, 31, 770.

21. Doyle, J. T., J. S. Wilson, and J. V. Warren. The pulmonary vascular responses to short-term hypoxia in human subjects. Circulation 1952, 5, 263.

22. Fishman, A. P., J. McClement, A. Himmelstein, and A. Cournand. Unpublished observations.

23. Swanson, A. G. Potential harmful effects of treating pulmonary encephalopathy with a carbon dioxide buffering agent. Amer. J. med. Sci. 1960, 240, 433.

24. Berman, L. B., T. F. O'Connor, and P. C. Luchsinger. Carbon dioxide buffering in man. J. appl. Physiol. 1960, 15, 393.

25. Brinkman, G. L., D. G. Remp, E. O. Coates, Jr., and E. M. Priest. The treatment of respiratory acidosis with THAM. Amer. J. med. Sci. 1960, 239, 341. 
26. Massaro, D. J., S. Katz, and P. C. Luchsinger. The use of a carbon dioxide buffer (Trishydroxymethylaminomethane) in the treatment of respiratory acidosis. Amer. Rev. resp. Dis. 1960, 86, 353.

27. Bergofsky, E. H., D. E. Lehr, and A. P. Fishman. The effect of changes in hydrogen ion concentration on the pulmonary circulation. J. clin. Invest. 1962, 41, 1492.

28. Fishman, A. P., H. W. Fritts, Jr., and A. Cournand. Effects of breathing carbon dioxide upon the pulmonary circulation. Circulation 1960, 22, 220.

29. Fishman, A. P., H. W. Fritts, Jr., and A. Cournand. Unpublished observations.

30. Nissel, O. I. The action of oxygen and carbon dioxide on bronchioles and vessels of the isolated perfused lungs. Acta physiol. scand. 1950, 21, suppl. 73.

31. Binet, L., and M. Burstein. Sur l'action vasoconstrictrice du sérum salé hypertonique au niveau de la petite circulation. C. R. Soc. Biol. (Paris) 1951, $145,1766$.

32. Binet, L., and M. Burstein. Sur les effets cardio-vasculaires du sérum salé hypertonique. C. R. Soc. Biol. (Paris) 1953, 147, 1997.

33. Eliakim, M., S. Z. Rosenberg, and K. Braun. Effect of hypertonic saline on the pulmonary and systemic pressures. Circulat. Res. 1958, 6, 357.

34. Semler, H. J., J. T. Shepherd, and H. J. C. Swan. Pressor effect of hypertonic saline on pulmonary circulation. Circulat. Res. 1959, 7, 1011.
35. Brutsaert, D., E. Lacroix, and I. Leusen. Influence de solutions hypertoniques sur la circulation pulmonaire. Acta cardiol. (Brux.) 1960, 15, 273.

36. Read, R. C., J. A. Johnson, J. A. Vick, and M. W. Meyer. Vascular effects of hypertonic solutions. Circulat. Res. 1960, 8, 538.

37. Read, R. C., and J. A. Vick. Cholinergic-like effects of hypertonic solutions. Amer. J. Physiol. 1961, 200, 233.

38. Maxwell, G. M., G. G. Rowe, S. Alphonso, C. W. Crumpton, and C. A. Castillo. The effect of sodium bicarbonate upon the general and cardiac hemodynamics and metabolism of the intact dog. Clin. Res. 1959, 7, 387.

39. Chidsey, C. A. III, H. W. Fritts, Jr., G. P. Zocche, A. Himmelstein, and A. Cournand. Effect of acetylcholine on the distribution of pulmonary blood flow in patients with chronic pulmonary emphysema. Mal. cardiovasc. 1960, 1, 15.

40. Staub, N. C. Gas exchange vessels in the cat lung. Fed. Proc. 1961, 20, 107.

41. Jameson, A. G. Diffusion of gases from alveolus to precapillary arteries. Science 1963, 139, 826.

42. Enson, Y., and A. Cournand. Respiratory variation in blood oxygen saturation within the great veins, right heart and pulmonary artery. Fed. Proc. 1963, 22, 516.

43. Ezekiel, M., and K. A. Fox. Methods of Correlation and Regression Analysis, 3rd ed. New York, John Wiley and Sons, 1959, p. 364. 